\title{
Narration of Architecture and Built form in the Context of Changing Urban Milieu
}

\author{
Ar. Bhagyalaxmi S Madapur ${ }^{1}$, Ar. Shanu Raina ${ }^{2}$, \\ ${ }^{1}$ Associate Professor, B M S College of Architecture, Bull Temple Road, Basavanagudi, Bangalore , \\ Karnataka , India \\ ${ }^{2}$ Assistant Professor, B M S College of Architecture, Bull Temple Road, Basavanagudi, Bangalore , \\ Karnataka, India
}

\begin{abstract}
Cities have the capability of providing something for everybody, only because, and only when, they are created by everybody' - Jane Jacobs
\end{abstract}

An urban area, with its complex landscape is the frontier of any modern world country offering enriching quality of life to its dwellers. Historically we have witnessed evolution of several resolute examples of great cities shaped by deep rooted understanding of environment, spatial and cultural preferences, and indigenous forms of knowledge, wisdom and skills. These great cities justifiably provided a backdrop for the progression of architecture and built form vocabulary positioned in a specific place and time.

However in the cities of developing countries like India, the rapidly changing urban environmental context which is epitomized through standalone built forms devoid of their contextual settings and its subsequent catastrophes such as degradation of natural and manmade landscapes, floods, water scarcity, congestion, deficiency of affordable housing, lack of accessible amenities, increasing non-inclusiveness (both spatially and socially), increasing mass of characterless manifestations of architecture and urbanism, etc. are rendering these urban areas as muddled models of unorganized growth. These mounting issues have been reflecting upon the fact that it is injustice to represent an urban area only through the lenses of unconnected architecture and built form.

Additionally, our architecture and urban design /planning discourses are increasingly being practiced within a paradigm borrowed from elsewhere which essentially do not recognize coexisting commons resulting in obvious paradoxes in the design and production of architecture and built form.

This paper attempts to shed light on the vital necessity of new narratives that are far more favoring in the advancement of comprehensive ecological thinking of the urban habitat where spheres such as environment, culture, spatial - social equity, economy, shelter, energy, water, food and mobility are seen as equally important contexts in the evolution of an urban milieu well balanced among its context, architecture and built forms.

Keywords: Architecture, Built form, Context, Urban Milieu, Narratives

\section{Introduction}


An urban area, with its complex landscape is the frontier of any modern world country offering enriching quality of life to its dwellers. The diversity of opportunity attracts people from rural areas to the cities (Arthur B. Gallion, 2003).54.5 percent of world population was living in urban settlements in 2016; approximately 60 percent of people globally are projected to reside in cities by 2030 . One million people globally resided in 512 cities in 2016. The number of cities will increase to 662 by 2030 year. Several cities in the global south (nations of Africa, Central and Latin America and most of Asia) are less developed and have limited resources at the same time out of 31 megacities in 2016, 24 were located in global south. It is increasingly apparent that socio-economic and environmental challenges offer opportunities for growth. Political mayhem, social non-cohesiveness and economic disruption are predominant in many cities of the global south. However, the emerging markets, international connectivity, trans-national practices, multi-cultured societies and changing housing dynamics offer growth projections which are continuously manifested in architecture, urban design and urban planning. The prior milieu emphasizes the portrayal of place production while depicting it to the academic and professional community.

\section{Urban area and its complex landscape}

Looking at cities can give a special pleasure; however commonplace the sight may be like a piece of architecture, the city is a construction in space, but one of vast scale, a thing perceived only in the course of long spans of time (Lynch, 1960). In words of Jane Jacob, Cities are an immense laboratory of trial and error, failure and success, in city building and city design (Jacob, 1960).

Earlier cities consisted of a series of buildings which over a period of time, as an architectural convention defined spatial order for the city as a whole. In contrast with this, the form of the modern city is often independent of individual acts of architecture, design and planning. Architecture was not an object in isolation, a piece of artistic gratification, but a medium to achieve larger humanitarian ends (Bhatia, 1994, p. 44). People from diverse cultures find common ground on a city's complex landscape which facilitates their innumerous activities. Spatial layouts of cities are the reflections of integrated physical setting that emulates multiplicity resulting in collective symbolic community memory which is nothing but 'sense of identity'.

\section{Evolution of Urban form}

The word city implies a concentration of people in a given geographic area who support themselves on a fairly permanent basis form the economic activities of that area. The city can be a center of industry, trade, education, government, or involve all these activities (Arthur B. Gallion, 2003). Following are the factors influencing and shaping the city form (Refer Table 1)

Table 1: Factors influencing and shaping city form

\begin{tabular}{|l|l|}
\hline $\begin{array}{l}\text { Factors Influencing and } \\
\text { shaping city form }\end{array}$ & Characteristics \\
\hline $\begin{array}{l}\text { Influence of Geography and } \\
\text { natural environment }\end{array}$ & $\begin{array}{l}\text { Location, extend and boundary, Climate, Water and Food } \\
\text { Availability, land characteristics, fertility, forest and bio - diversity } \\
\text { and minerals }\end{array}$ \\
\hline Power and Administration & Type of leadership \\
\hline $\begin{array}{l}\text { Socio - Cultural and } \\
\text { Anthropomorphic }\end{array}$ & $\begin{array}{l}\text { Origin and influence, major contemporary events, social grouping, } \\
\text { cultural pattern, language, religion, literature and fine arts }\end{array}$ \\
\hline Socio - Economics & Trade and commerce - commodities and trade linkages \\
\hline
\end{tabular}


\begin{tabular}{|l|l|}
\hline & $\begin{array}{l}\text { Technology - influence in industries, building and construction, } \\
\text { transportation, utilities and services. }\end{array}$ \\
Source: (Sengupta, 2006)
\end{tabular}

The history of human settlement can be classified into three broad categories (Sengupta, 2006):

- Ancient phase (12000B.C - 3,000 B.C)

- Intermediate phase or Medieval phase (3000 B.C - 1500A.D)

- Modern phase of organized phase (1500A.D- Till date)

The first settlement evolved in Mesopotamia and the valley of Tigris and Euphrates rivers, approximately 5000 years ago. Agriculture thrived at the river valley civilizations and soon there was surplus of the goods. This lead people to start venturing in to the other skills and the trading began. The trading became the starting point of urbanization. Figure below explain the evolution of man from its primitive living to living in today's cities (Refer Figure 1).

Figure 1: Various concepts of idea livable city by eminent planners

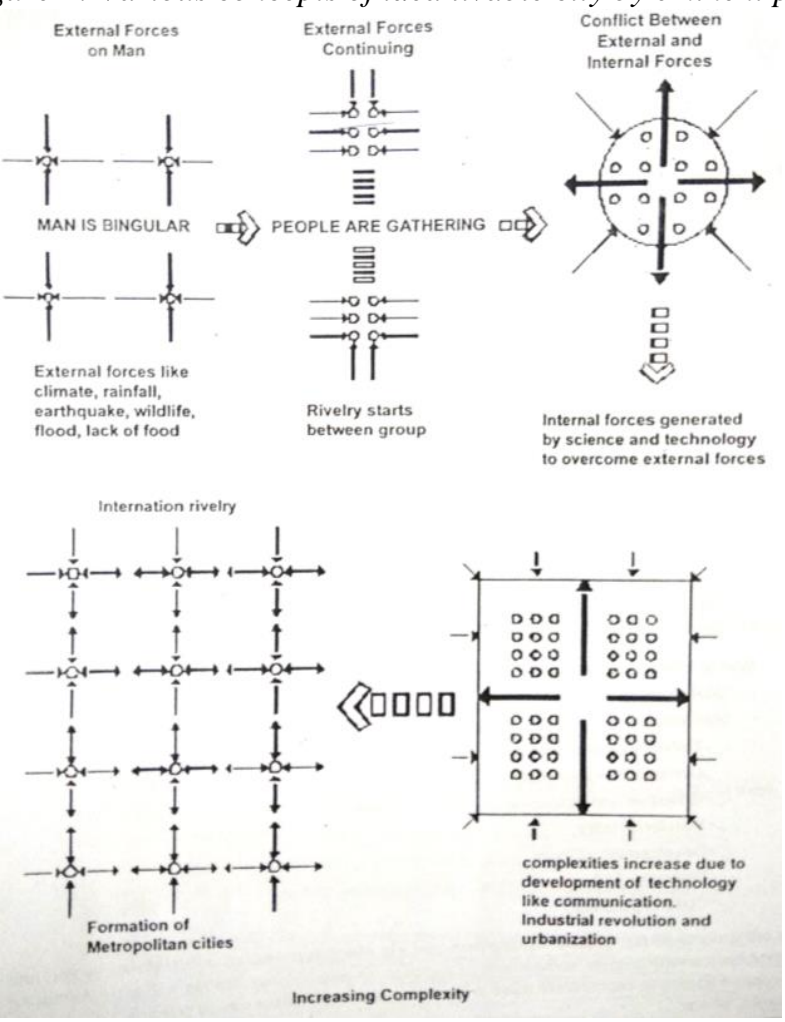

Source: (Sengupta, 2006)
Historically we have witnessed evolution and flourishment of several resolute examples of great cities and societies shaped by deep rooted understanding of environment, spatial and cultural preferences, indigenous forms of knowledge, wisdom and skills in a symbiotic manner. Prior to industrial revolution as well as aftermath of it, cities have dominated their contextual settings influencing every aspect of its inhabitants and their daily lives.

\section{Transition to the Industrial city}

The industrial areas were the magnet for economic growth and provide numerous employment opportunities resulting in migration of people. These industrial areas soon expanded and became metropolis. Capitalism of the industrial system with few entrepreneurs as the proprietors of many industries led to monopolistic situation (Sengupta, 2006). With coming of railways, development of suburbs started. After Henry Ford made cars affordable for the public by enlarge in start of $20^{\text {th }}$ century, the shape of the cities changed. Coming of automobiles increased the mobility of people by many folds. The industries were now core of the cities. The cities during this time were congested, lacked housing facilities, poor infrastructure, unhygienic living conditions etc. It was at this time that most of the planners felt the need to curb congestion and hence proposed different theories of how an idea livable city should be (Refer Table 2). 
Table 2: Various concepts of idea livable city by eminent planners

\begin{tabular}{|c|c|c|}
\hline $\begin{array}{l}\text { Pioneer City } \\
\text { Planners }\end{array}$ & Examples of cities & Concept \\
\hline Ebenezer Howard & $\begin{array}{l}\text { Letchworth Garden } \\
\text { City (1903) } \\
\text { Welwyn Garden city }\end{array}$ & $\begin{array}{l}\text { - Garden City. } \\
\text { - Smoke less and slum less cities. } \\
\text { - A total of } 6000 \text {-acre estate. } \\
\text { - } 1000 \text { acres for central garden city, which will } \\
\text { house a population of } 32,000 \text {. } \\
\text { - } 5000 \text { Acres of land surrounding central green } \\
\text { retained for agriculture and to house } 2000 \text { people. }\end{array}$ \\
\hline Tony Garnier & $\begin{array}{l}\text { Modern Industrial city } \\
\text { (1917) }\end{array}$ & $\begin{array}{l}\text { - The idea was to plan a modern city. } \\
\text { - Civic centre and residential zones to be bifurcated } \\
\text { from industrial zone by creating green belt. } \\
\text { - Highways and railway tracks not to have any } \\
\text { development abutting the regional route of the } \\
\text { communication. }\end{array}$ \\
\hline Patrick Geddes & Tel- Aviv (1910) & $\begin{array}{l}\text { - House is an inseparable entity of the } \\
\text { neighbourhood, the city and surrounding open } \\
\text { country and region. }\end{array}$ \\
\hline Soria Y. Mata & Linear City (1882) & $\begin{array}{l}\text { - Expansion of the industrial cities in concentric } \\
\text { form increases the distance between the } \\
\text { countryside and urban population. } \\
\text { - Pedestrian scale to be the determinant of the total } \\
\text { width of the linear city. } \\
\text { - City expand on the spine of communication - the } \\
\text { highway. }\end{array}$ \\
\hline Le Corbusier & $\begin{array}{l}\text { Concentric City } \\
(1922) \\
\text { Radiant City }\end{array}$ & $\begin{array}{l}\text { - Tower in a park concept. } \\
\text { - High density high rise surrounded by green space. } \\
\text { - Creation of super block and segregation various } \\
\text { land uses. } \\
\text { - sought to eradicate the physical complexity of } \\
\text { traditional cities, setting the stage for automobile } \\
\text { dependency and single-use functional zoning } \\
\text { (Hall, 2014). }\end{array}$ \\
\hline $\begin{array}{l}\text { Ludwing } \\
\text { Hilbersemier }\end{array}$ & The High-rise city & $\begin{array}{l}\text { - Organization scheme of relations between parts } \\
\text { was the key to city planning. } \\
\text { - Communal blocks instead of single house unit. } \\
\text { - The idea of high rise city as a socialist city. } \\
\text { - Activities to be vertically stacked. } \\
\text { - All the housing to be stacked with public sector } \\
\text { or institutions. } \\
\text { - This was to solve the problem of commuting. }\end{array}$ \\
\hline Clarence Stein & Radburn city & $\begin{array}{l}\text { - The elementary school should be in the centre and } \\
\text { all the residential units should be half mile radius. } \\
\text { - House enough people to require the elementary } \\
\text { school. } \\
\text { - No through traffic through the residential area- } \\
\text { Cul-de-sacs to be given to avoid the through } \\
\text { traffic. } \\
\text { - The group of three such units to have high school } \\
\text { and a major commercial centre with one mile of } \\
\text { radius. } \\
\text { - All the sides should be equidistant from the } \\
\text { centre. }\end{array}$ \\
\hline
\end{tabular}




\begin{tabular}{|l|l|l|}
\hline Frank Lloyd Wright & Broadacre (1932) & $\begin{array}{l}\text { - One house unit per acre. } \\
\text { - It was the plan which was opposite of transit- } \\
\text { oriented development. } \\
\text { - The city to have a train station, offices and } \\
\text { apartments buildings etc. the apartments dwellers } \\
\text { to be expected in less numbers. } \\
\end{array}$ \\
& $\begin{array}{l}\text { - Pedestrians to exist within the one-acre plots } \\
\text { where most of the population resides and the } \\
\text { major transport is done by automobiles. }\end{array}$ \\
\hline
\end{tabular}

\section{Desolate Cityscape- A Case of Indian Cities}

A city, with the passage of time is continually influenced by physical, socio-economic and cultural parameters. Thus, its urban form is the manifestation of diverse existential

Figure 2: Unregulated Development

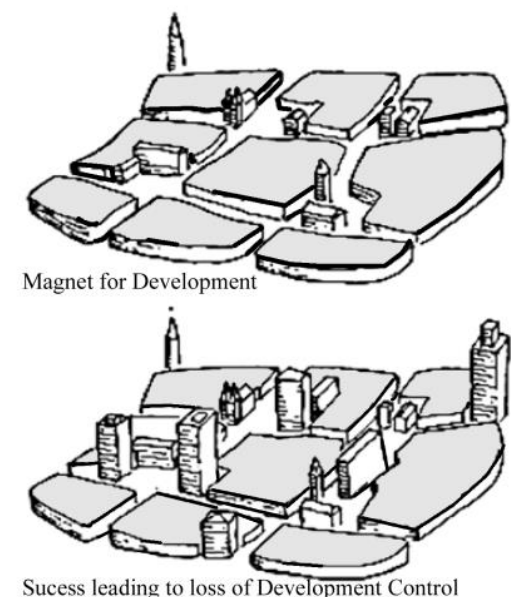

Sucess leading to loss of Development Control

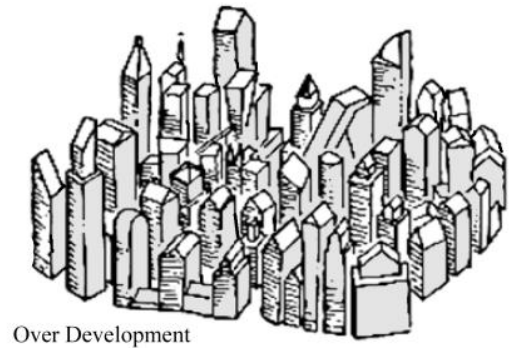

Source: Authors dimensions crystalized as urban spaces forming the cityscape and strengthens the 'sense of place'. India's initial evolution of globalized economy thrived on the notions of modernism on the proposition of inclusivity. But over a period of time, it has disseminated a mass trans-national culture leading eventually to loss of sense of identity encompassing the spheres of tradition, culture, languages, art, etc. India's urbanization is followed by some basic problems in the field of: 1) housing, 2) slums, 3) transport 4) water supply, sanitation, 5) water pollution, air pollution, 6) inadequate provision for social infrastructure (school, hospital, etc). Class I cities such as Calcutta, Bombay, Delhi, Madras have reached saturation level of employment generating capacity.

With the geometric jump in urbanization forcing cities to be symbols of economic development coupled with rapidly surging population, built environment is manifesting into visible expressions of a dislocated global archetype dominating the cityscape of Indian cities. Cityscape is the visual horizon upon which city dwellers engage with their daily activities (Refer Figure 2 ). If this visual horizon is composed of discontinuous and disharmonic elements, it affects the physical as well as notional perceptions of the city dwellers.

Architecture of the built environment is the most evident and expressive imagery of creation and transformation shaping the sense of self, space and place. The combined impact of global economic reformation and the international style, is overwhelmingly erasing the built environment that is a strong expression of socio-cultural aspect while paving way for uniformly looking structures and spaces that are devoid of any due considerations for the physical and socio-cultural settings lacking sensory stimulation. 


\subsection{Indigenous Urban Planning}

The spirit of Indian cities is that they contain a myriad of diverse and intense nterconnected vibrant activities. Several well researched evidences shed light on the fact that India's strong historical past of more than two thousand years had town planning as a key characteristic feature in the conceptualization and planning of towns and associated systems.

Planning for towns and cities in India dates back to Vedic times with examples such as Varanasi, Nalanda, Patliputra, Takshashila, etc. which were structured on the principles derived from well informed systematic approaches encompassing diverse dimensions (political, socio-economic, cultural, geographical, ecological, etc.) of the society. These early approaches have resulted in the crystallization of robust, intellectual and organized body of Indigenous knowledge.

The collage of earlier townscape / cityscape mirrored thoughtful expressions of political, socio-economic and environmental frameworks that reinforced the collective spirit of the place.

\subsection{Metamorphosis of Indian Cities}

In the last two decades, Indian cities are witnessing dramatic transformation from extensively being walkable to automobile bound urban sprawl leading to the fragmentation of cities' character while disconnecting the social interaction. The other, more formidable majority of urban practitioners seek to align their work with the more favourable idea of India as an industrial power. It is a view of exploration. If the country is to enter the global economic stage, there is a price to be paid in misery, hardship and forsaken human rights; if conventional development is to occur, it may create imbalances in ecology and environment; but the end result makes it all worthwhile. Progress is measured by the Gross National Product, and architectural work by the numbers of new offices, factories and shopping complexes realized within one fiscal year (Bhatia, 1994, p. 17).

Currently, Indian cities are increasingly getting morphed into models of uneven modernization and subsequently incomplete urbanization. The rapidly changing urban environmental context which is epitomized through standalone built forms devoid of their contextual settings and its subsequent catastrophes such as degradation of natural and manmade landscapes, floods, water scarcity, congestion, deficiency of affordable housing, lack of accessible amenities, increasing non-inclusiveness (both spatially and socially) increasing mass of characterless manifestations of architecture and urbanism, etc. are rendering these urban areas as muddled models of unorganized growth. However, some of the architects perhaps made more acutely aware of the country's heritage and the depletion of its resources began creating architecture consistent with regional solutions. The works of Raj Rewal, Romo Khosla, Vasant and Revathhi Kamanth and Ashish Ganju among others in Delhi; B.V Doshi, Anant Raje and Jaimini Mehta in Ahemdabad; Charles Correa in Bombay and Laurie baker in Trivandrum, all mirror, and question - to an extent- the relevance of working to a specifically local idea. Each of these architects has formed personal view of history that is supportive of their own interpretation of place and society (Bhatia, 1994, p. 10).

Besides, our existing and so-called futuristic cities are being steadily modelled on the discourses essentially borrowed from antiquated Western theories, narratives and images. Over the past several decades, with the obsessed ambition of being relevant in the accelerated 
transitional globalization and conform to models of growth which essentially do not recognize co-existing commons is resulting in cities which hardly have any type of intellectual references for its natural or cultural settings. Also, the adoption of narratives which have been architecture and built form intensive to represent the cityscape through sheer scale and size have been aggravating the snags resulting in obvious paradoxes of imagining the cityscape and urban form.

\subsection{Spatial Vacuum between Buildings and spaces}

Uncontrolled sprawl fueled by land conversion for different land uses, transportation networks and major redevelopments with their imposing presence occupying large tracts of lands are replacing diversity of the city fabric lacking all sensory stimulation and sense of place. Rapidly growing trends in transitional global economies and advancements in the telecommunication fields are heralding that the 'place is no longer significant'. These occurrences are further reinforced by huge austere conurbations which neither connect with the social fabric nor reflect the identity of a city. Traditional city landmarks such as public buildings, market places, recreation spaces, etc. which were symbols of socio-cultural character are increasingly being replaced by modern landmarks that indicate commercialism (Refer figure 3).

Figure 3: (Top)Basic Modern Building Types, (Bottom) Functional Monotony - Architectural Pathologies
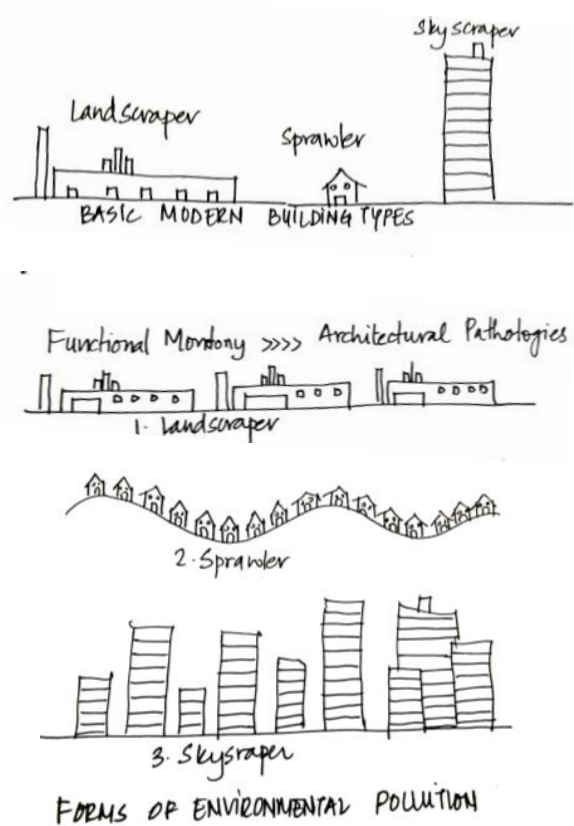

Source: Authors

\section{Architecture, Urban Design and Urban Planning as Social Tools}

For a common city dweller who is overwhelmingly buried under the age-old problems, architecture, design and planning are mere backgrounds. In the current world, architecture is being perceived as a product showcasing the interest of few individuals rather than focusing on the collective interests of communities. In developing societies such as Indian cities, strategies of form and place making are synonymous with the process of modernization symbolizing the modernism. This modernist vision is raising profound questions, unraveling the ideals of professionals and the expectations of the user groups.

For several decades, the contours of the imaginations of the contemporary Indian architects, urban designers and urban planners have failed to engage with the fundamental issues and challenges of the built environment. Architectural institutions, urban design and planning institutions, professionals and legislations are lagging behind and have lost themselves in the extremes of the micro and macro scales. They have abandoned the tangible environment, the soil, the water, the energy and its finite resources to be processed by crude design and planning tools. Architecture, urban design and urban planning continue to emphasize on highly fragmented and compartmentalized process for the creation of the built 
form. Professionals tend to ignore the patterns generated by socio-economic and cultural imperatives while preparing blue prints for city master plans and architectural strategies. They have tendency to follow the heavily borrowed unfamiliar 'imagery' to achieve only aesthetics rather than dealing with the complexities of everyday urbanism. These professionals need to change their perceptions of the way they conceive buildings and the city at large by realigning to confront the problems at hand and not seek conformity with the developments occurring elsewhere.

Development of architecture, design and planning professions as social tools for an understanding of its genesis to provide effective strategies:

\subsection{Understanding city as a cohesive form}

The primary concern of urban morphology is the structure of urban form and the urban form in turn is the result of internal structures of urban areas. The major morphological factors of cities include natural determinants (climate, topography and local materials available for construction) and manmade determinants (involve politics, religions, defense, planning and functioning). The current trends that are yielding vivid patterns of urban form are the result of un-related, un-connected and most importantly un-coordinated attempts practiced by a wide spectrum of people including policy makers, citizens, urban planners, urban designers, architects and engineers.

Several core overlapping morphological measures such as land use, development regulations, physical and social infrastructure, built form environment, public realm, green/open spaces, user profile can be analyzed to develop quantifiable methods which can be used as indices by planners, designers as well as policy makers to formulate a framework of different schemes to steer the city towards elevating the quality of urban living.

Figure 4: The Compact City

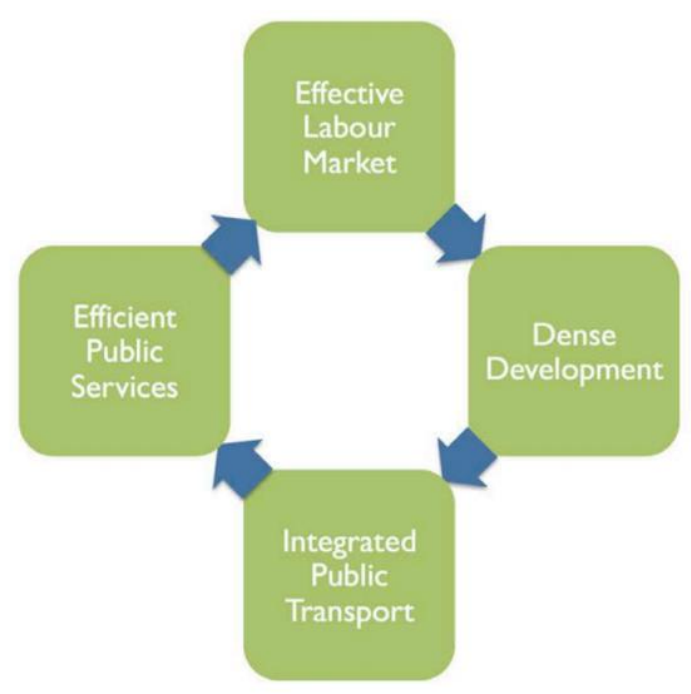

Source: Authors

\subsection{People Centered Urbanism- Experiencing city at $5 \mathrm{Km} / \mathrm{hour}$}

Cities are for people and hence the focus should be on emphasizing the human scale enriched with visual imagery and interconnected hierarchy of spaces as well as built forms to promote social encounters on daily basis. People centered urbanism creates social capital, interactions and spatial experiences resulting in vibrant public realm.

Medium to high density area with diversity and short distance access to different activities / services coupled with public transit stops can create conducive physical setting to experience city on foot. To positively support this aspect, a built environment must have a sufficient pedestrian network to make accessible area. Variables such as environment, network and destination are the primary effective parameters of built environment and related experiential qualities reinforcing human scale (Refer Table 3). 
Table-3: Effective Parameters of Built Environment on experiential qualities

\begin{tabular}{|c|c|c|}
\hline Variables & Features & Parameters \\
\hline Environment & $\begin{array}{l}\text { At the human scale, active transport } \\
\text { permits for maximum appreciation and } \\
\text { experience of the urban area. } \\
\text { High density neighbourhood encourages } \\
\text { mixed use development improving } \\
\text { accessibility to various functional and } \\
\text { recreational activities associated with } \\
\text { active transport. }\end{array}$ & $\begin{array}{ll}\text { - } & \text { Aesthetics } \\
\text { - } & \text { Safety } \\
\text { - } & \text { Building } \\
& \text { orientation }\end{array}$ \\
\hline Network & $\begin{array}{l}\text { A network provides safe and comfortable } \\
\text { use of active transport. }\end{array}$ & $\begin{array}{ll} & \text { Accessibility } \\
\text { - } & \text { Sidewalks } \\
\text { - } & \text { Cross walks } \\
\end{array}$ \\
\hline Destination & $\begin{array}{l}\text { Active transport street system is efficiently } \\
\text { used if the network provides different } \\
\text { levels of access to various destinations. }\end{array}$ & $\begin{array}{ll}\text { - } & \text { Land use mix } \\
& \text { and pattern } \\
\text { - } & \text { Diverse } \\
& \text { activities } \\
\end{array}$ \\
\hline
\end{tabular}

Source: Authors

Several studies in public health domain contemplate premeditated active transport as one of the decisive factors in enhancing urban dwellers' quality of life. Active transport and human powered transportation include walking, cycling and variants such as cycle rickshaws, skateboards, push scooters, hand carts, etc. These modes provide both transportation and recreation and are especially important for short trips that form the largest share of trips in urban areas.

\subsection{Equitable Societies - Shattered individual islands or part of living communities}

In the past twenty years, extent and consequence of migration has increased manifold. Migrants tend to concentrate in clusters of thriving city agglomerations. This has led to urban polarization leaving other areas in a state of economic stagnation in turn reducing the

Figure 5: The Sprawling City

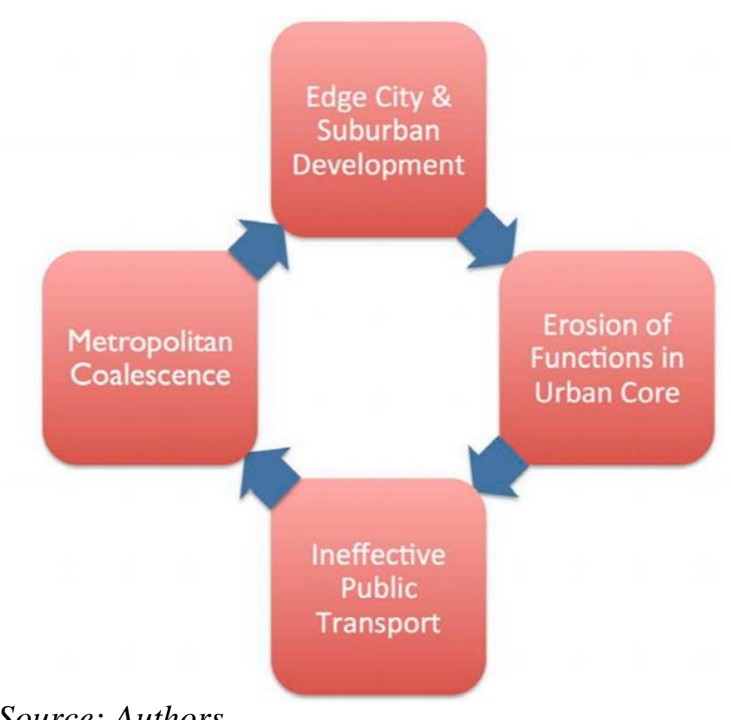
opportunities for positive social interaction and cohesion. Developing vibrant urban areas can assist in mitigating migratory pressure on cities and manage urbanization processes.

Most of the time certain concepts of architecture and urbanism are superficially understood and are applied leading to the creation of a bias as well as an intellectual void overwhelming the local context and identity.

\subsection{Environment}

Air and water pollution, flooding and heat waves are most prevalent environmental issues resulting from urban sprawl. Urban sprawl has increased and resulted in growing unregulated consumption of land. Urban life, culture and activities are greatly impacted by the environmental setting and are further influenced by the built form. Built environment is 
the largest consumer of depleting resources. Hence, city dwellers, professionals and public sector should encourage adoption of time tested building principles (employing local skills, methods and materials) to ensure holistic growth with high emphasis placed on environmental sustainability.

\subsection{Cities serve human beings or human beings serve cities- Economy, Shelter, Water- Energy-Food and Mobility}

A range of economic, socio-cultural associations as well as gender and age influence the way in which individuals are affected by or use of the built environment. Cities offer economies of scale with regard to provision of civic and utility amenities such as mobility, water, energy, food, solid waste management. Specific aspects such as priorities of location, level of development of the shelter and tenure that determine dwelling environment change over a period as the situation of the urban dweller changes. Financial crisis and lack of adequate affordable housing especially for vulnerable groups is a critical matter leading to increased spatial and social segregation.
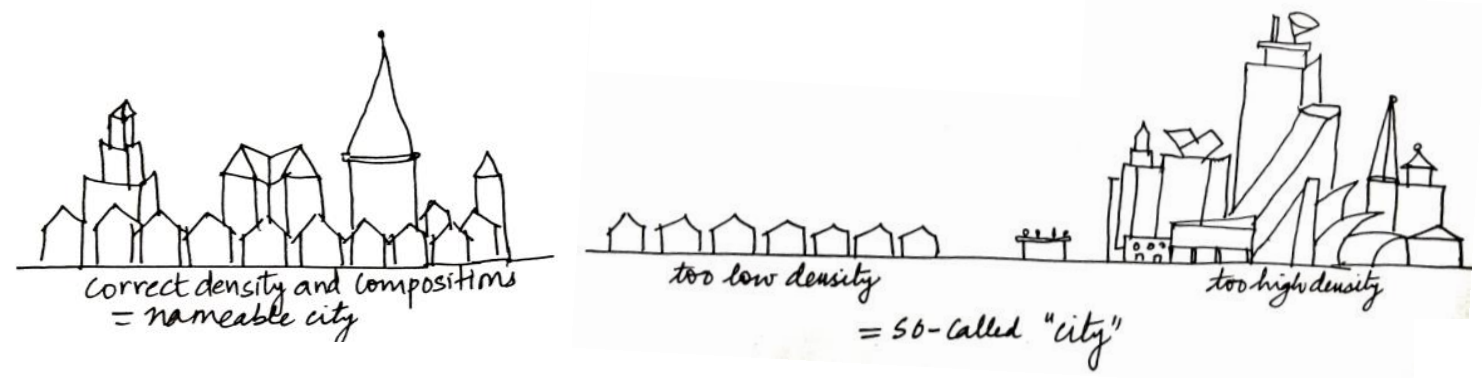

Source: Authors

Continued collaboration, consensus action among authorities, stakeholders and communities is required to develop a trend towards people centered and integrated planning process to address complex socio-cultural, economic and environmental challenges.

\section{Discussions and Way Forward}

The very nature of city planning and practice of architecture need paradigm shift into experimental territory away from a naive understanding of quantified requirements into design ingenuity to respond to the pressing need of switching, modernizing and upgrading.

In a stressful urban situation, radical narratives and interpretations that cascade beyond the conventional approach to sway from the piecemeal renewals stems as the most appropriate innovation for the urban future. Furthermore, these radical narratives and interpretations should not only be based on economy and technology but socio-cultural facets to breed a range of well-informed solutions to the challenges and issues of the cities. In India, architecture, design and planning is creating an unequal society of those who can conform to its imperatives and those cannot - certainly the majority cannot. Hence, this particular aspect 
offers an opportunity to develop diverse innovative narratives. Emerging narratives have to accept the simultaneous validity of difference to address the multiplicities and co-existences can be spatially structured (Refer Table 4).

Table 4: Emerging domains of narratives and their respective scope

\begin{tabular}{|c|c|c|}
\hline $\begin{array}{l}\text { Sl. } \\
\text { No. }\end{array}$ & $\begin{array}{l}\text { Domains of } \\
\text { Narratives }\end{array}$ & Scope \\
\hline 1 & $\begin{array}{l}\text { Multilateral } \\
\text { Partnerships }\end{array}$ & $\begin{array}{l}\text { Structuring constituencies based on multilateral Partnerships } \\
\text { comprised of city dwellers, bureaucrats and politicians to engage with } \\
\text { the complex landscape of the Indian democracy. }\end{array}$ \\
\hline 2 & Regulatory & $\begin{array}{l}\text { Proposed innovative planning and inventive architectural designs } \\
\text { which extend their scope beyond the site and requirements to } \\
\text { contribute to civic, conservation, environmental and artistic causes } \\
\text { should be granted permission and approved for construction. }\end{array}$ \\
\hline 3 & Participatory & $\begin{array}{l}\text { Common and protective ownership values allow city dwellers to } \\
\text { participate in the city building process. }\end{array}$ \\
\hline 4 & $\begin{array}{l}\text { Professional } \\
\text { (Architects, Urban } \\
\text { planners \& Urban } \\
\text { designers) }\end{array}$ & $\begin{array}{l}\text { To stay relevant and to collectively develop new approaches, } \\
\text { professionals must transcend substantially beyond the silos of } \\
\text { disciplines and extend their roles as promoters of sensible built forms } \\
\text { for active engagement with the society. }\end{array}$ \\
\hline 5 & $\begin{array}{l}\text { Architectural, Urban } \\
\text { planning and Urban } \\
\text { Design pedagogy }\end{array}$ & $\begin{array}{l}\text { Pedagogy and training to build capacity to be propositional and } \\
\text { venture about the future while augmenting a healthy dialogue } \\
\text { between the old and new. } \\
\text { Appropriate curricula must be created to respect the 'context' besides } \\
\text { undertaking capacity building. This aspect should be a progressive } \\
\text { force to mediate the challenges of future urbanization. }\end{array}$ \\
\hline 6 & $\begin{array}{l}\text { Advocacy and } \\
\text { professional } \\
\text { involvement in } \\
\text { decision making and } \\
\text { bureaucracy }\end{array}$ & $\begin{array}{l}\text { Support through on field action. } \\
\text { Creation of tools or instruments for advocacy- communicating, } \\
\text { writing, researching, dissemination of information, etc. }\end{array}$ \\
\hline 7 & $\begin{array}{l}\text { Active professional } \\
\text { practice (Architecture, } \\
\text { Urban Planning \& } \\
\text { Urban Design) }\end{array}$ & $\begin{array}{l}\text { Professionals have to pursue the snags to create synergies among } \\
\text { disciplines and recognize new forms of patronage to envisage the } \\
\text { solutions leading to novel narratives. } \\
\text { The strategies for the architecture, urban design and urban planning } \\
\text { should eliminate the debilitating characteristics of professional } \\
\text { indifferences and to dialogue and negotiate with the users, society } \\
\text { and policy makers in the design and planning developments. }\end{array}$ \\
\hline 8 & Public Realm & $\begin{array}{l}\text { Planning for the community: Private realm needs to be exchanged } \\
\text { with public realm to regain the interconnected urban community. }\end{array}$ \\
\hline 9 & $\begin{array}{l}\text { Built form typologies } \\
\text { and urban spaces }\end{array}$ & $\begin{array}{l}\text { 1. Public Buildings: } \\
\text { Public buildings such as government buildings, public facilities, } \\
\text { religious structures, institutions and organizations that have symbolic } \\
\text { functions can be the edifices of architectural design. } \\
\text { 2. Pivotal and contextual buildings (the physical and } \\
\quad \text { metaphorical focus) for common uses and habitation: } \\
\text { Contextual design frameworks for this typology will assist in } \\
\text { restoring functional and aesthetic urban milieu. } \\
\text { Public buildings together with pivotal and contextual buildings } \\
\text { define, provide and contain interconnected urban spaces constantly } \\
\text { crafting interesting visual imagery. }\end{array}$ \\
\hline
\end{tabular}

Source: Authors

Each development framework needs to encompass conscious choices based on ordered strategy, scheme and design specific to a neighborhood's physical setting so that accidental 
character could be alleviated. This approach enhances the quality of the urban environment, encourages active transport (walking / cycling), supports built forms and active engagement of inhabitants with their surroundings. Active and engaged citizenship in the development of cohesive urban form would assist in shifting the course of cities away from the revenue maximization towards the welfare of the community. Places are enhanced by shared architectural character of the built forms which are environmentally and socio-economically resilient responding effectively in time and space while co-relating the past to the future. Indian cities need to be self-referential to contain and address the heterogeneity. The time is now to foreground a 'sense of appropriateness' to the local context as the strong global currents are broadcasting the creation of architecture, urban design and urban planning through innovative narratives in the context of changing urban milieu to eco the social ethos and identity. Indian cities need to be modelled on a plurality (temporal- social- economical) of overwhelming multicultural society, wide social and economic disparity all positioned in a context of democracy to be increasingly spatially - socially inclusive, be economically prosperous and be optimistic about the future.

\section{References}

[1] Arthur B. Gallion, S. E. (2003). The Urban Pattern City Planning and Design. New Delhi: CBS Publisher \& Distributors.

[2] Bhatia, G. (1994). Silent Spaces and other stories of Architecture. Delhi: Penguin Books India (P) Ltd, pg 10.

[3] Hall, P. (2014). Cities of Tommorrow: An Intellectual History of Urban Planning and Design since 1880. WILEY Blackwell.

[4] Jacob, J. (1960). The life and Death of Great American Cities. New York: Vintage Books.

[5] K, D. (1965). The Urbanisation of Human Population. Scientific American, 41-53.

[6] Kundu, A. (1994). Sectoral Issues in the Indian Economy, Pattern of Urbanisation with Special Reference to Small and Medium Towns in India in Chadha, G. K. New Delhi: Har - Anand Publication.

[7] Lynch, K. (1960). The Image of the City. Cambridge, Massachusetts, and London, England: The M.I.T Press.

[8] Sengupta, B. (2006). History of Human Settlements. New Delhi: ITPI. 